\title{
Information Seeking Behaviour of Selected Woman Entrepreneurs of Parbhani City
}

\author{
Jayshree Rodge* and Maya Jadhav \\ Department of Resource Management and Consumer Science, College of Community Science, \\ VNMKV., Parbhani, Maharashtra, India \\ *Corresponding author
}

Keywords

Self employed, woman, information seeking

Article Info

Accepted:

12 June 2021

Available Online:

10 July 2021
The present study entitled "Information seeking behaviour of selected woman entrepreneurs of Parbhani city" was conducted in the Parbhani city. For this study 200 woman entrepreneurs were randomly selected from Parbhani city. Scale developed by using normalized rank approach to obtain the Entrepreneurial Behaviour score. After obtaining the E.B. scores with the developed questionnaire an entrepreneurial behavior index was calculated. It was found that mean score of behavior of the selected respondents was very low for their participation in information seeking. There was no single effective information source always contacted by the selected respondents for seeking information regarding entrepreneurship. Information seeking was high among the young (20 to 25 years) and educated (post graduate) respondents. Respondents having high income (more than Rs. 21168) were earned more monthly average profit (more than Rs. 3839). Age was negatively correlated with the information seeking, while education, income and social participation of the respondents were the highly significantly correlated factor with the information seeking behavior of the respondents.

\section{Introduction}

It refers to the degree of frequency of contact by an individual with various information sources. This is the pattern by which a women entrepreneur gets her information either on her own seeking or as consequences of her being a part of a network. (Schook and Mathews 1974)
Much of the process of creating and growing business involves seeking and interpreting information. Relevant information improves the accuracy of decisions and leads to ventures success. Seeking and interpreting information help entrepreneurs deal with a variety of strategic, administrative, and operational problems. Information scanning "is like radar that informs the entrepreneur about conditions 
he/she is likely to encounter". In addition, gathering and interpreting information is also related to entrepreneurial learning. Information increases entrepreneurs' knowledge and expertise.

The entrepreneur is a key resource in the business and the quality of the entrepreneur as a resource is dependent upon their knowledge.

Keeping this into mind the present study is initiated where decision making character of selected woman entrepreneurs of Parbhani city was studied with following objective:

\section{Objective}

To study the information seeking character of selected woman entrepreneurs of Parbhani city with respect to there personal, economical and social

\section{Materials and Methods}

For this study 200 woman entrepreneurs were randomly selected from Parbhani city.

The questionnaire consisted questions regarding general information and scale developed by using normalized rank approach recommended by Guilford (1954) to obtain the E.B. score. After obtaining the E.B. scores with the developed questionnaire an entrepreneurial behavior index was also calculated by using the following formula.

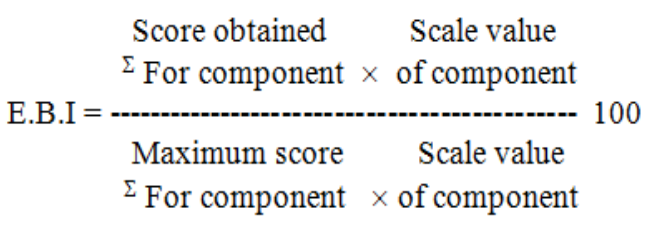

Social participation scale developed by Choudhary and Sing (1964) was used to measure the social participation of the respondent. Statistical analysis of the data was carried out using ANOVA.

\section{Results and Discussion}

It is observed from the study that majority (38\%) of self employed woman belonged to the age group of 31- 35 years, 44.5 per cent were found to be educated up to high school level. Majority 58.5 per cent self employed woman belonged to the families having 5-8 members and having more than 9 family members $(6.5 \%)$. Family income of maximum self employed woman $(68 \%)$ in present study was in the range of Rs. 8939/- to 21167/- per month having average monthly profit earned by majority of the respondents $(55.5 \%)$ was within the range of Rs. 1219/- to 3838/- per month.

Frequency and percentage of self employed women contacting various sources of information for development of entrepreneurial activities is illustrated in figure 1. It is clear from the figure that majority of entrepreneurs (92\%) were seeking the information of enterprise through frequent discussions, followed by magazine (50\%), local entrepreneurs (49.5\%) and radio/ television (38\%). Figure 1 illustrates that 100 percent respondents reported that they were never contact scientist from Home Science college. It was also reported that melawa (96.5\%), MCED (96\%), news papers (65\%), training programme $(52.5 \%)$ and exhibition $(51.5 \%)$ were sometimes used by self employed women as information source for their business venture.

Information seeking level of the respondents in entrepreneurial behaviour according to selected activities relating to personal and family characteristic are shown in table 1 .

\section{Age}

The table 1 indicates that the mean score behavior of self employed women regarding information seeking was very low i.e. ranging from, 3.51 to 6.25. Maximum involvement in 
information seeking activities (6.25) was by 20 to 25 years aged respondents. Data revealed that as the age of the self employed women increased the mean score behavior regarding information seeking decreases. The data indicates that the age of the respondents was negatively highly significant factor influencing their information seeking behavior $\left(r=-0.258^{* *}\right)$.

\section{Education}

It is evident from the table 1 that mean score behavior regarding information seeking character was highest in post graduate respondents (10.8) and minimum in primary educated respondents (2.8).

Higher secondary education level and graduate education level did not showed much difference in their mean score behavior i.e. 5.7 and 5.9. Overall there was increasing trend of mean scores behavior regarding information seeking character and education level of the self employed women. Education of the respondents was found to be highly significant correlated factor with information seeking behavior $\left(\mathrm{r}=0.465^{* *}\right)$.

\section{Family size}

The mean score of behavior related to information seeking was more (5.2) among the self employed women belonging to the family having 1 to 4 members than that of families with 5 to 8 members (4.67) and more than 9 members (4.69). Statistically non significant correlation was found between the number of members in the family and information seeking behavior.

Information seeking level of the respondents in entrepreneurial behaviour according to selected activities relating to economic characteristic is depicted in table 2 .

\section{Monthly average profit}

It is evident from the table that means score behavior on information seeking was more (5.2) among the respondents earned monthly average profit more than RS. 3839 and mean score of behavior on information seeking was less (3.9) among the respondents earned monthly profit up to Rs. 1218. The amount of monthly average profit earned by the respondents was not statistically correlated with mean score of behavior related to information seeking.

\section{Family income}

From the table no. 2 it was found that all the respondents (19\%) from low income range i.e. income up to Rs. 8938 had low mean score behavior for information seeking. Thirteen percent and 4.5 percent respondents from income range Rs. 8939 to 21167 and more than Rs. 21168 participated in information seeking at moderate level. Mean score behavior regarding information seeking was highest (6.2) in high income range. self employed women mean score behavior of information seeking character was increased as the family income of women entrepreneurs increased. Statistical test was applied to the data it was found that, family income was influenced information seeking behavior of the respondents. The result for factor family income was similar with the findings of Muradi (1995).

Information seeking level of the respondents in entrepreneurial behaviour according to selected activities relating to social characteristic is given in table 3 . 
Table.1 Entrepreneurial Behaviour of Information Seeking Regarding Enterprise with Respect to the Personal and Family Characteristics of self employed women

\begin{tabular}{|c|c|c|c|c|c|}
\hline \multirow[t]{2}{*}{ Character } & \multicolumn{3}{|c|}{ Level } & \multirow{2}{*}{$\begin{array}{l}\text { Mean } \\
\text { score }\end{array}$} & \multirow{2}{*}{$\begin{array}{c}\text { Correlation } \\
\text { coefficient }\end{array}$} \\
\hline & $\begin{array}{l}\text { Low } \\
\text { (165) }\end{array}$ & $\begin{array}{l}\text { Medium } \\
\text { (35) }\end{array}$ & $\begin{array}{l}\text { High } \\
\text { (Nil) }\end{array}$ & & \\
\hline $\begin{array}{c}\text { 1. Age } \\
1.20-25 \\
2.26-30 \\
3.31-35 \\
4.36-40 \\
5.41 \text { and above }\end{array}$ & $\begin{array}{c}16(8) \\
26(13) \\
63(31.5) \\
41(20.5) \\
19(9.5)\end{array}$ & $\begin{array}{c}4(2) \\
10(5) \\
13(6.5) \\
4(2) \\
4(2)\end{array}$ & $\begin{array}{l}-- \\
-- \\
-- \\
-- \\
--\end{array}$ & $\begin{array}{l}6.25 \\
5.86 \\
4.88 \\
3.51 \\
4.69\end{array}$ & $-0.258 * *$ \\
\hline $\begin{array}{l}\text { 2. Education } \\
\text { 1. Primary } \\
\text { 2. High school } \\
\text { 3. Higher secondary } \\
\text { 4.Graduate } \\
\text { 5.Post graduate }\end{array}$ & $\begin{array}{c}24(12) \\
81(40.5) \\
42(21) \\
18(9) \\
--\end{array}$ & $\begin{array}{c}-- \\
8(4) \\
13(6.5) \\
8(4) \\
6(3)\end{array}$ & $\begin{array}{l}-- \\
-- \\
-- \\
-- \\
--\end{array}$ & $\begin{array}{c}2.86 \\
4.15 \\
5.75 \\
5.92 \\
10.83\end{array}$ & $0.465 * *$ \\
\hline $\begin{array}{c}\text { 3. Family size } \\
\text { 1. } 1-4 \text { member } \\
\text { 2. 5-8 members } \\
\text { 3.9 \& above members }\end{array}$ & $\begin{array}{c}53(26.5) \\
100(50) \\
12(6)\end{array}$ & $\begin{array}{c}17(8.5) \\
17(8.5) \\
1(0.5)\end{array}$ & $\begin{array}{l}-- \\
-- \\
--\end{array}$ & $\begin{array}{l}5.21 \\
4.68 \\
4.69\end{array}$ & $-0.007^{\mathrm{NS}}$ \\
\hline
\end{tabular}

Figures in parenthesis indicate percentage * - Significant at $5 \%$ level

** - Significant at $1 \%$ level NS - Non significant

Table.2 Entrepreneurial Behaviour of Information Seeking level of the respondents in entrepreneurial behaviour according to selected activities relating to economic characteristic

\begin{tabular}{|c|c|c|c|c|c|}
\hline \multirow{2}{*}{ Character } & \multicolumn{3}{|c|}{ Level } & Mean & $\begin{array}{c}\text { Correlation } \\
\text { score } \\
\text { coefficient }\end{array}$ \\
\cline { 2 - 5 } & $\begin{array}{c}\text { Low } \\
(165)\end{array}$ & $\begin{array}{c}\text { Medium } \\
(35)\end{array}$ & $\begin{array}{c}\text { High } \\
\text { (Nil) }\end{array}$ & & \\
\hline 1. Monthly Average Profit & & & & & $0.134^{\mathrm{NS}}$ \\
1. Rs. 0-1218 & $39(19.5)$ & $4(2)$ & -- & 3.91 & \\
2. Rs. 1219-3838 & $91(45.5)$ & $20(10)$ & -- & 5.06 & \\
3. Rs.3839 \& above & $35(17.5)$ & $11(5.5)$ & -- & 5.28 & \\
\hline 2. Family Income & & & & & $0.384^{* *}$ \\
1. Rs. 0-8938 & $38(19)$ & -- & -- & 2.71 & \\
2. Rs. 8939-21167 & $110(55)$ & $26(13)$ & -- & 5.21 & \\
3. Rs.21168 \& above & $17(8.5)$ & $9(4.5)$ & -- & 6.23 & \\
\hline
\end{tabular}

Figures in parenthesis indicate percentage * - Significant at $5 \%$ level ** - Significant at $1 \%$ level NS - Non significant 
Table.3 Entrepreneurial Behaviour of Information Seeking level of the respondents in entrepreneurial behaviour according to selected activities relating to social characteristic

\begin{tabular}{|c|c|c|c|c|c|}
\hline \multirow{2}{*}{ Character } & \multicolumn{3}{|c|}{ Level } & Mean & Correlation \\
score & coefficient \\
\cline { 2 - 5 } & $\begin{array}{c}\text { Low } \\
(165)\end{array}$ & $\begin{array}{c}\text { Medium } \\
(35)\end{array}$ & $\begin{array}{c}\text { High } \\
\text { (Nil) }\end{array}$ & & \\
\hline Social Participation & & & -- & 9.13 & \\
1. No Participation & $13(6.5)$ & $11(5.5)$ & $-358^{* *}$ \\
2. Low Participation & $14(7)$ & $74(37)$ & $13(6.5)$ & 12.82 & \\
3. Medium Participation & $3(1.5)$ & $36(18)$ & $15(7.5)$ & 13.98 & \\
4. High Participation & -- & $15(7.5)$ & $6(3)$ & 14.62 & \\
\hline
\end{tabular}

Figures in parenthesis indicate percentage * - Significant at $5 \%$ level ** - Significant at $1 \%$ level NS - Non significant

Fig.1 Information Sources of self employed women

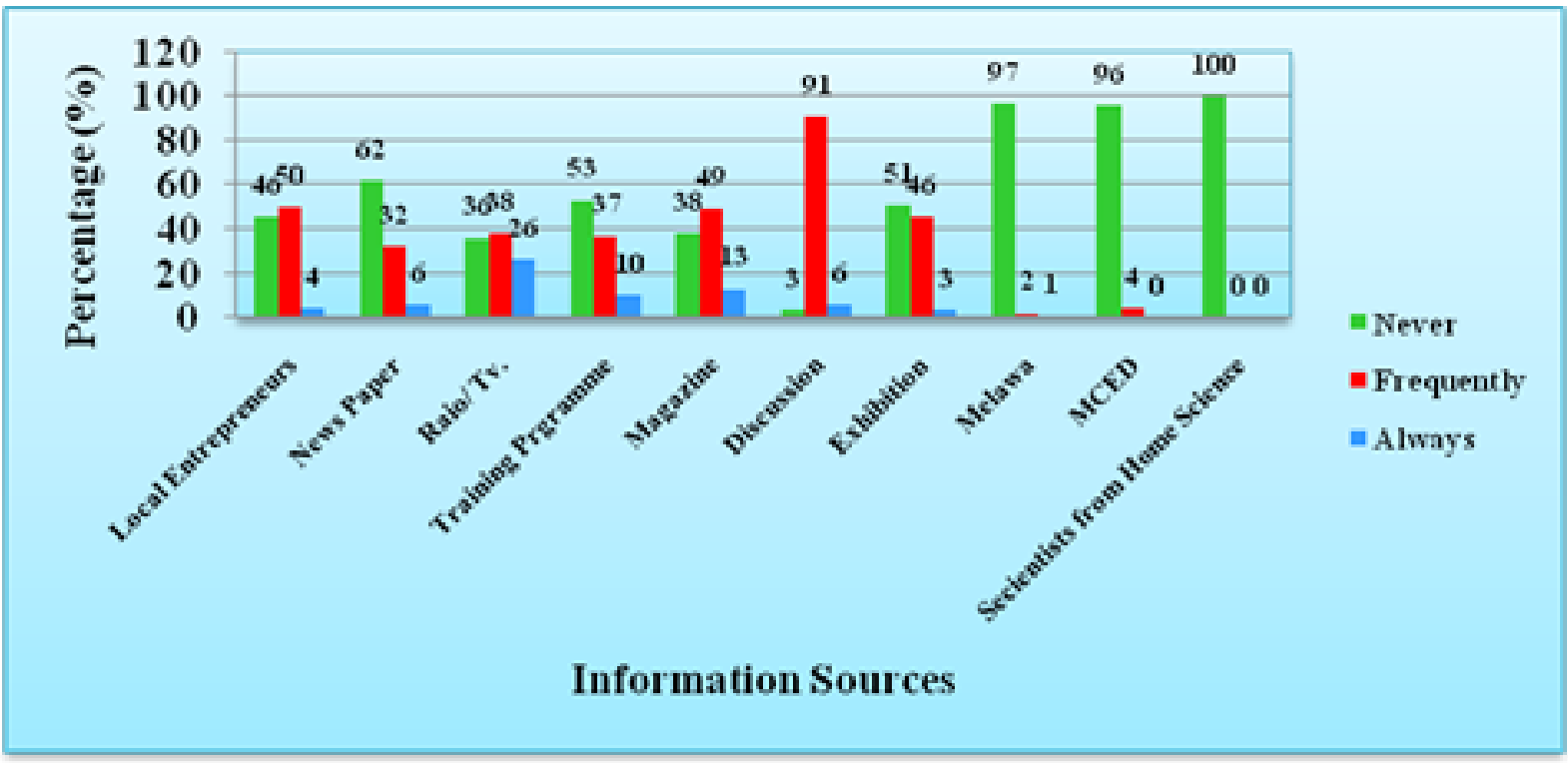

\section{Social participation}

It is clear from the table 3 that mean score behavior regarding information seeking character was highest in high social participation of respondents (14.6) and minimum when no social participation (9.1). Low social participation of respondents showed 12.8 mean score of behavior for information seeking while medium social participation of respondents showed 13.9 mean score of behavior for information seeking. Social participation of the respondents was found to be highly significant correlation factor with their information seeking behavior $\left(\mathrm{r}=0.358^{* *}\right)$. The results for factor social participation was inline with the results of Jadhav (2016).

The mean score of behavior of the selected respondents was very low for their participation in information seeking. There was no single effective information source always contacted by the selected respondents for seeking information regarding entrepreneurship. Information seeking was high among the young (20 to 25 years) and educated (post graduate) respondents. 
Respondents having high income (more than Rs. 21168) were earned more monthly average profit (more than Rs. 3839). Age was negatively correlated with the information seeking, while education, income and social participation of the respondents were the highly significantly correlated factor with the information seeking behavior of the respondents.

\section{References}

Chaudhari, S. S. and Singh, S. N. (1964). Social participation scale measurement in Extension Research Instruments at IARI, New Delhi, p 36-48.

Guilford, J. P. (1956). Fundamental statistics in psychology and education, McGraw
Hill Book Co., New York, p: 171-173. Jadhav Maya and Rodge Jayshree (2016). Entrepreneurial behavior of self employed women in Parbhani. Unpublished M. Sc. Thesis submitted to Vasantrao Naik Marathawada Krishi Vidyapeeth, Parbhani, p:74-78.

Muradi, M. B. (1995). Entrepreneurial Behaviour of self employed women in Parbhani District. Unpublished M. Sc. Thesis submitted to Marathawada Agricultural University, Parbhani, p: 10-25.

Schook, B. F. and Mathews, L. B. (1974). Identifying extension opinion leaders, Journal of Extension, Vol. 12 (3): 1624.

\section{How to cite this article:}

Jayshree Rodge and Maya Jadhav. 2021. Information Seeking Behaviour of Selected Woman Entrepreneurs of Parbhani City. Int.J.Curr.Microbiol.App.Sci. 10(07): 124-129.

doi: https://doi.org/10.20546/ijcmas.2021.1007.014 